\title{
Obstetrical epidural anaesthesia in a Canadian outpost hospital
}

The number of parturients receiving epidural anaesthesia in universiny medical centres is increasing. This trend is not paralleled in rurat hospitals. Obsterrical epidural anaesthesia as provided in a 40-bed, remote hospital is reviewed for the ten-year period from January 1974 to December 1983. Charts were reviewed retrospectively for 116 patients undergoing epidural blockade. The indications, complication rates, as well as infant outcomes were noted. Seven per cent of all parturients received epidural anaesthetics. Ninety per cent of this group received systemic sedation or narcotics prior to epidural catheter insertion. Nineteen patients $(16.3$ per cent $)$ experienced a major complication, including four dural punctures (3.4 per cent), ten episodes of significant hyposension (8.6 per cent), blood vessel punciure during carheter insertion in four patients ( 3.4 per cent), and transient paresthesia in one paient $(0.8$ per cent). Considerations for the provision of epidural anaesthesia in a remote hospital are discussed.

Epidural blockade is an important adjunct for the obstetrical anaesthetist. The use of epidural analgesia for vaginal delivery and epidural anaesthesia for Caesarean section is increasing. ${ }^{1.2}$ The benefits of this technique, however, are not available to many parturients in rural hospitals. ${ }^{3}$

In Canada, small hospitals service a vast territory and a large proportion of the Canadian population. Statistics from the 1980 Canadian Hospital Directory indicate that over 40,000 infants were born in centres performing less than 400 deliveries per year. ${ }^{4}$ Thirty per cent of these, or 12,000 infants, were delivered in centres performing less than 100 deliveries per year. These mothers and infants are unlikely to have access to anaesthetic specjalists. Family doctors and general practitioner-anaesthetists play a major role in the care of these patients. In a recent survey of British Columbian Hospitals, 86.6 per cent of the

\section{Key wards}

ANAESTHESIA: Obstetric; ANAESTHESIA, REGIONAL: epidural; COMPLICATIONS: geographic location.

From the Department of Anaesthesia, Toronto Western Hospital, 399 Bathurst Street, Toronto, Ontario, MST $2 S 8$. anaesthetists in community hospitals were non-specialists. ${ }^{3}$ These practitioners are challenged continually to maintain their skills and knowledge. Despite the numbers, they rarely address their concerns in the Canadian anaesthesia literature. It is hoped that this publication will stimulate critical appraisals in other isolated medical centres and promote a high standard of anaesthetic care.

The Baic Verte Medical Centre in northem Newfoundland has provided a limited epidural anaesthesia service for over a decade. The following report is a retrospective study of obstetrical epidural anaesthesia for the ten-year period from January 1974 to December 1983. The review identifies the indications and complications associated with its use.

\section{Methods}

Baie Verte Medical Centre is a forty-bed hospital. It serves a population of 12,000 , composed primarily of residents from the surrounding outports. The average obstetrical load is 166 deliveries per year. The nearest obstetrical referral centre is three hours away by road, weather permitting. The hospital is staffed by six salaried physicians. The anaesthesia service is provided by familypractice anaesthetists who have completed a three- to six-month anaesthesia training program at a university centre.

The charts of patients in whom epidural anaesthesia was initiated, as noted in the delivery room records, were reviewed by the author for the period of January 1974 to December 1983. Data extracted from the charts included patient's age, parity, indications for epidural blockade, stage of labour, insertion technique, supplemental sedation, method of delivery, infant Apgar scores and any complications noted during epidural insertion or maintenance of epicural blockade. Apgar scores not recorded on the matemal charts were obtained from the neonatal records. The accuracy of this review was limited by the precision with which complications were identified and recorded by medical and nursing personnel.

\section{Results}

During the review period, there was a total of 1657 
TABLE I Indications for epidural blocks

\begin{tabular}{lrr}
\hline Indication & $n$ & $\%$ \\
\hline Analgesia & 55 & 47.4 \\
Syntocin induction, prolonged ruptured & & \\
$\quad$ membranes & 4 & 3.4 \\
Failure to progess: & 19 & 16.3 \\
$\quad$ dysfunctional labour & & \\
$\quad$ occiput posterior & 17 & 14.6 \\
Pre-eclampsia & 1 & 0.8 \\
Twins & 4 & 3.4 \\
Breech & 16 & 13.7 \\
Elective Caesarcan section & 0 & 0 \\
Emergency Caesarean section & 115 & \\
&
\end{tabular}

deliveries, of which 1369 (82.6 per cent) were vaginal deliveries and 288 (17.3 per cent) Caesarean sections. One hundred and sixteen (seven per cent) of patients received epidural anaesthesia. The number of epidural blocks per year varied from one to 28 . Epidural anaesthetics were performed by nine different family practitioneranaesthetists over the ten-year period. The number of available anaesthetists skilled at epidural blockade varied from one to three at any one time.

Fifty-two patients (44.8 per cent) received sedation (pentobarbitone, secobarbitone) and 53 (45.6 per cent) of patients received narcotics (meperidine, morphine) prior to epidural blockade.

The most frequent indication for epidural blockade was analgesia during the first stage of labour (47 per cent; Table 1). The obstetrical indications, as noted in the records, included pre-eclampsia (14.6 per cent) and failure to progress (14.6 per cent). Epidural blockade was usually initiated toward the later phase of the first stage of labour when systemic medication failed to provide adequate pain relief (Table II).

The method of delivery is outlined in Table III. Twenty-three (19.8 per cent) patients underwent spontaneous vaginal delivery, sixty-one ( 52.5 per cent) had forceps or vacuum assistance, four were assisted breech extraction, and twenty-eight ( 24 per cent) were delivered

TABLE II Timing of epidural block

\begin{tabular}{lr}
\hline & $n$ \\
\hline Elective Caesarean prior & 12 \\
to onset of labour & 9 \\
Cervical dilation $\leq 3 \mathrm{~cm}$ & $\$ 2$ \\
$4-6 \mathrm{~cm}$ & 40 \\
$7-10 \mathrm{~cm}$ & 3 \\
Not recorded at time of & $\overline{116}$ \\
insertion & \\
\hline
\end{tabular}

TABLE III Method of delivery

\begin{tabular}{lrl}
\hline & $n$ & \% \\
\hline Spontaneous vaginal & 23 & 19.8 \\
Forceps & 43 & 37.0 \\
Vacuum extraction & 18 & 15.5 \\
Breech assistediextraction & 4 & 3.4 \\
Caesarean section & 12 & 10.3 \\
$\quad$-elective & 16 & 13.8 \\
- emergency & - & \\
& 116 & \\
\hline
\end{tabular}

by Caesarean section. A total of 117 infants were delivered. One hundred and five neonates had Apgar scores at one minute greater than seven. Eight infants had scores between five and seven while two infants scored less than five. One was the product of a difficult midforceps delivery, the other a breech extraction. One infant was stillborn, with multiple congenital anomalies. Epidural blockade did not appear to have contributed to neonatal depression in the cases reviewed.

All patients were moved from the labour room to the post-anaesthetic room for epidural catheter insertion. This facility was equipped with maternal and neonatal resuscitation equipment and drugs. All patients had an intravenous catheter inserted and balanced salt solution infused. The "loss of resistance" technique was employed to identify the epidural space. The agents used included lidocaine 0.5-2 per cent, bupivacaine 0.25-0.75 per cent* with and without epinephrine 1:200,000. The records frequently failed to document the use of a test dose, the total volume of anaesthetic drug employed, and the volume of "preload" intravenous fluid administered prior to epidural blockade.

The incidence of complications is illustrated in Table IV. There were no identified subarachnoid injections or intravascular injections. Inadvertent dural tap occurred in four (3.4 per cent) cases. Two patients experienced post-partum headaches that responded to conservative therapy. Hypotension, defined as a decrease in systolic BP greater than 20 per cent or less than $80 \mathrm{mmHg}$, occurred in ten ( 8.5 per cent) patients and was the most frequent major complication. Minor complications occurred in 23 (13.8 per cent) of patients.

In nine of the 28 patients ( 32 per cent) undergoing Caesarean section, the epidural anacsthesia was considered inadequate or inappropriate and a general anaesthetic was employed. This included several failed attempts to identify the epidural space. Other than the two patients

*Bupivacaine 0.75 per cent is no longer employed in Baie Verte for epidural injection. 
TABLE IV Complications

\begin{tabular}{lcl}
\hline & $N$ & $\%$ \\
\hline Major & 4 & 3.4 \\
Dural tap & 4 & 3.4 \\
Puncture vessel & 0 & 0 \\
Toxic reaction & 6 & 5.1 \\
Hypotension - nild & 4 & 3.4 \\
Paralysis - * severe & 0 & 0 \\
Transient paresthesia & 1 & 0.8 \\
Subarachnoid injection & 0 & 0 \\
& 19 & \\
Minor & & \\
Shivering & & \\
Back pain & 6 & 5.1 \\
Failed attempt & 2 & 1.7 \\
Patchy block & 6 & 5.1 \\
Urinary retention & 2 & 1.7 \\
& 7 & 6.0 \\
\hline
\end{tabular}

* Systolic pressure decreased $>20$ per cent or $<80 \mathrm{mmHg}$

that experienced a patchy block, the records did not indicate the quality of analgesia provided.

\section{Discussion}

The proportion of patients (seven per cent) receiving epidural analgesia was less than that reported from larger university affiliated centres ( $29-45$ per cent).$^{3-5}$ In Baie Verte, the lack of an available experienced anaesthetist and the difference in patient expectations and acceptance resulted in the more frequent use of systemic medication. Over 90 per cent of patients received sedation or narcotics prior to epidural injection. The depressive effects of these drugs on the newborn is well recognized. ${ }^{6}$ This practice does not parallel trends in the larger obstetrical centres where few patients receive sedation. ${ }^{1,2}$

There were no life-threatening complications such as accidental subarachnoid or intravascular injection. Dural tap occurred in 3.4 per cent of attempts versus $1-4.7$ per cent previously reported from other centres. An increased incidence of accidental dural tap has been associated with lack of experience of the operator. ${ }^{7,8}$

A major anaesthetic-related complication occurred in 16.3 per cent of patients compared with a $4.2-10.5$ per cent incidence reported from other university and community hospitals. ${ }^{9.10}$ The Baie Verte patients, however, were further along in labour, were experiencing a higher incidence of obstetrical complications and had been sedated previously.

These results generate concern regarding the efficacy and safety of this practice. Epidural anaesthesia should be employed only if adequate safety standards are met. The Canadian Anaesthetists' Society has recommended the
TABLE V Guidelines for continuous infusion epidural administration of local anaestheties for pain relief in childbirth*

1 Epidural anaesthesia should be established after appropriate consent bas been received from the patient, and with the agreement of her obstetrician.

2 Patient shoutd be nursed in a room equipped with oxygen supply and suction. All appropriate monitoring equipment and drugs for resuscitation, should be immediately available.

3 An intravenous infusion should be scanted.

4 A calibrated infusion purmp should be used. The epidural infusion tubing should have no distal infusion sites.

5 The local anaesthetic solution should be clearly labeled.

6 Monitoring: The following should be monitored at regular interials and recorded:

(i) Mother: (a) Blood pressure and heart rate

(b) Levels of sensory and motor blockade.

(c) Uterine activity.

(ii) Fetal: (a) Heart rate, cither intermittently or preferably by continuous monitoring.

(iii) Rate of infusion of analgesia drug.

7 A physician who is capable of managing any of the complications associated with this technique, including respiratory or cardiac arrest, must be immediately available

8 After stopping the epidural infusion, the patient must be observed by properly trained staff until adequate recovery of motor and sensory function has occurred.

"As recommended by the Canadian Atraesthetists' Society. "

guidelines in Table $\mathrm{V}$ for continuous epjdural administration of local anaesthetics for pain relief in childbirth. " Similar standards should be adopted by all anacsthetists for intermittent or single-dose epidural anaesthesia.

There was a noticeable number of epidural anaesthetics judged inadequate for Caesarean section (32 per cent). This was likely a result of difficulty locating and cannulating the epidural space, inadequate dose of local anaesthetic or failure to wait for the onset of sufficient blockade. Many of the complications identified above resulted from lack of experience. An anaesthetic skills update in a large obstetrical centrc would improve technique and increase the likelihood of an effective block.

The presence of nine different anaesthetists in Baie Verte over a ten-year period attests to the difficulty in attracting clinicjans to remote communities. Most provinces now require that family practice-anaesthetists complete a training program in a Department of Anaesthesia approved by the Royal College of Physicians and Surgeons of Canada. ${ }^{9}$ Guidelines are currently being developed by the Canadian Medical Association, the Canadian Anaesthetists' Society and the Canadian College of Family Practice to set minimum training requirements for all family practitioner-anaesthetists. Continued access to university departments is of equal importance when the anaesthetic case load fails to maintain the practitioner's skills. Specialists and family practitioner-anaesthetists must work in concert to define training requirements. 
The more perplexing problem of shortage of skilled personnel in rural hospitals, the logistics of retraining programs and renumeration for the anaesthetist that must remain available during epidural analgesia are beyond the scope of this paper. These issues, however, require further address if parturients are to experience a safe, more comfortable delivery in rural Canadian hospitals.

\section{References}

1 Ong B, Cohen MM, Cumming M, Paiahniwh RJ. Obstetrical anaesthesia at Winnipeg Wornen's Hospital 1975-83: anesthetic techniques and complications. Can J Anaesth 1987, 34. 294-9.

2 Murphy JF, Dauncey M, Rees GAO, Rosen M, Gray $O P$. Obstetrical analgesia, anaesthesia and the Apgar scone. Anaesthesia 1984, 39: 760-3.

3 McMorland GH, Jenkins LC, Douglas MJ. A survey of obstetric anaesthesia practice in British Columbia. Can Anaesth Soc J 1986, 33: 2: 185-94.

4 Finch, $K$ (ed): Canadian Hospital Directory, Canadian Hospital Association, Ottawa, 1981.

5 Walton $P$, Reynolds $F$. Epidural analgesia and instrumental delivery. Anaesthesia 1984, 39: 218-23.

6 Corke $B C$. Neurobehavioral responses of the newborn, the effect of different forms of maternal analgesia. Anaesthesia 1977, 32: 539-43.

7 Crawford JS. The second thousand. Epidural blocks in obstetrical hospital practice. Br J Anacsth 1972, 44: $1277-87$.

8 Brownridge $P$. A three year survey of an obstetrical epidural serviee with top-up doses administered by mid-wives. Anaesth Intensive Care 1982, 10: 298-308.

9 Rudick V, Niv D, Golan A, er al. Epidural analgesia during labor in 1,200 monitored parturients. Israel J Medical Science 1983, 19:20-24.

10 Adamson DM. Continuous epidural anacsthesia in the community hospital. Can Anaesth Soc J 1973, 20: 687-91

11 Guidelines to the Practice of Anaesthesia. Canadian Anaes. thetists' Society Newsletter. Vol. 2, No. 3, Sept. 1986.

12 College of Physicians and Surgeons of B.C. Proposed Guidelines for the Practice of Anaesthesia in the Province of British Columbia. Vancouver. The College.

\section{Résumé}

Le nambre de parurientes stubissant the anesthésie épidurale dans les centres médicaux universilaires est croissant. Cetie tendance n'est pas suivie parallèlemem dans les hôpitaux ruraur. L'anesthésie épidurale obstétricale administréc dans un hôpitai de 40 lits en région éloignée est revue pour une périade de dix ans de janvier 1974 à décembre 1983. Les dossiers ont été revus rérrospectivemem pour 116 patientes ayant subi un bioc épidural. Les indications, les taux de complicatiom, aussi bien que les issues chez les nouveatr-nés ont été notés. Sept pour cent de toutes tes parturientes ont reçu des anesshésiques par voie épidurale. Quatre-vingt-dix pour cent de ce groupe ont reçu une sédation systémique ou des narcotics avant l'insertion du cathéler épidural. Dix-neuf patientes (16.3 pour cent) ont eu des complications majeures incluant quatre ponctions de la duremère (3.4 pour cent), dix épisodes d'hypotension significative (8.6 pour cent). quatre patientes ont ele the ponction des vaisseaux (3.4 pour cent) et une patiente a démonté de ta paresthésie (0.8 pour cêtt). Les considérations pour l'éfablissement de lanesthésie épidurale dans un hôpital éloigné sont discutées. 